Araștırma Makalesi / Research Article

\title{
16. Yüzyılın Sonlarında Balkanlarda Bir Maden İsletmesi: Kamengrad Demir Madeni
}

\section{Mehtap Çelik*}

(ORCID ID: 0000-0002-5675-0121)

\author{
Gönderim Tarihi \\ (Submitted)
}

27.07.2020
Kabul Tarihi

(Accepted)

19.08.2020

\author{
Yayın Tarihi \\ (Published)
}

30.09 .2020

\section{Atıf Bilgisi/Reference Information}

Chicago: Çelik, M., "16. Yüzyılın Sonlarında Balkanlarda Bir Maden İ̧̧letmesi: Kamengrad Demir Madeni", Vakanüvis-Uluslararası Tarih Araştırmaları Dergisi, 5/2 (2020): 587-610.

APA: Çelik, M. (2020). 16. Yüzyılın Sonlarında Balkanlarda Bir Maden İşletmesi: Kamengrad Demir Madeni. Vakanüvis-Uluslararası Tarih Araştırmaları Dergisi, 5 (2) , 587-610.

Öz

Bu makalede, Osmanlı maliyesinin en önemli gelir kaynaklarından birisi olan maden işletmelerin örgütlenme ve yönetim biçiminin mikro düzeyde bir örnekle irdelenmesi amaçlanmaktadır. Osmanlı iktisat tarihi üzerine yapılan çalışmalarda, klasik dönemde madenlerle ilgili olan araştırmaların sayısı oldukça azdır. Bu nedenle araştırmamız, Osmanlı malî ve idarî tarihine katkı sağlaması açısından oldukça önemlidir.

Fatih döneminde Anadolu ve Balkanlarda önemli bir güç haline gelen Osmanlı devletinin, bu bölgelerde bulunan maden ocaklarını neredeyse tamamıyla ele geçirerek hem malî hem de askerî açıdan kendi kendine yeterlilik politikasına da yön verebildiği ve maden ocaklarının işleyişini kontrol altında tutup, üretimin aksamaması için klasik dönemin başlarından itibaren sürekli

\footnotetext{
* Dr. Öğr. Üyesi, Mersin Üniversitesi, Fen-Edebiyat Fakültesi, Tarih Bölümü, Türkiye, meehtaab@gmail.com.

PhD in History- Faculty Member, Mersin University, Faculty of Arts and Sciences, Department of History, Turkey.
}

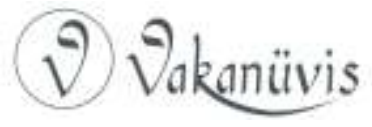


maden kanunnameleri yayınlayarak, madenlerin hukukî statüsünü sağlamlaştırmaya çalıştığı görülmektedir.

Bilindiği gibi Balkanlar, gümüş, demir ve bakır maden yatakları bakımından zengin bir bölgeydi. Çalışmamıza konu olan maden işletmesinin bulunduğu Bosna'da altın ve gümüş madenlerinin yanında oldukça verimli demir madenleri de bulunmaktaydı. Iş̧te bunlardan birisi de 16. yüzyılın sonlarına doğru işletmeye açılan Kamengrad demir madenidir.

Osmanlı askerî sanayisinin ihtiyaç duyduğu önemli hammaddelerden birisini sağlayan Kamengrad demir madeni devlet denetimi altında işletilmiştir. Madenin ve aynı zamanda maden reâyâsının korunmasında da son derece hassas davranan devlet, bu maden ocağında üretimin aksamadan devam etmesi için gerekli bütün önlemleri almış ve böylece genelde ordunun özelde ise etraftaki kalelerin top mermisi mühimmatını sağlamaya çalışmıştır.

Anahtar Kelimeler: Bosna, Kamengrad, maden, demir, top mermisi.

\section{A Mining Processing Facility in the Balkans during the Late $16^{\text {th }}$ Century: Kamengrad Iron Mine}

\section{Abstract}

In this paper, the form of organization and management of iron facilities that were among the important resources of revenue for the Ottoman state treasury is aimed to be elaborated by focusing on a micro-scale geography. The number of studies concentrating on the issue of mining facilities is very limited amongst the studies focusing on the Ottoman economic history and conducted for the classical era. Hence, this study is important as a contribution to the Ottoman financial and administrative history.

It is observed that the Ottoman Empire turning into an important power in the Anatolia and Balkans during the era of Fatih Sultan Mehmet captured almost all of the mining sites in these territories as it facilitated self-sufficiency policy of the Empire in terms of both financial and military concerns, and consequently tried to improve the legal status of mining sites by continuously issuing mining code of laws (kanunnâme) starting from the beginning of the classical era in order to keep the mining facilities under control and to prevent disruption in production.

As it is known, Balkans was a region of rich silver, iron and copper ores. There were rich mines of iron in Bosnia, where the case study area is located, in addition to gold and silver mines. And one of these mines was Kamengrad iron mine that was put into operation towards the end of the $16^{\text {th }}$ century.

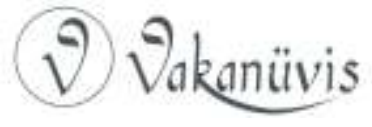


Kamengrad iron mine providing one of the important raw materials required in the Ottoman manufacturing system industry was operated under the control. The Empire acting sensitively in the protection of both the mines and reâyâ (the Ottoman subject class composed of mainly peasants and farmers) working in these mines took all the necessary precautions in order to sustain the production of iron in this mine without any interruption, and by doing so, tried to meet, in general, the army's, and in particular nearby castles' demand for cannonball ammunition.

Keywords: Bosna, Kamengrad, mine, Iron, cannonball.

\section{Giriş}

Bu makalede; Osmanlı devletinin askerî ve malî organizasyonunda önemli bir yere sahip olan maden yataklarının işleyişi ve bu organizasyonda karşılaşılan problemler, Bosna'da bulunan Kamengrad demir madeni üzerinden ele alınacaktır. Literatürde Osmanlı devletinde maden ve maden yatakları ile çalışmalar mevcuttur. Nitekim Kamengrad demir madeni üzerine yapılan çalışmamızda da klasik dönemde maden üretiminin mikro düzeyde boyutları ortaya konularak, bu dönemdeki mevcut bilgilerimize katkıda bulunmak hedeflenmektedir.

Bilindiği gibi top, tüfek gibi ateşli silahların kullanımı madenlerle yakından ilgilidir. Osmanlı klasik döneminin başlarından itibaren devletin yöneticilerinin pragmatik davranışları, onların ateşli silah teknolojisini kullanabilmelerini sağlamıştı. Ateşli silahlarla donatılmış Avrupa ordularıyla sürekli çatışma içinde olmasının yanı sıra, Bizans'ta, Akdeniz'de ve Macaristan'da güçlü kalelerin bulunması Osmanlı ordusunu buna zorlamıştı. Bu bağlamda Osmanlı devletinin seri üretim yapabilmesi ve üstün lojistik güçleri, onları Avrupa karşısında üstün duruma getirdiği ve bu üstünlüklerini 17. yüzyılın sonlarına kadar koruyabildikleri görülmektedir. ${ }^{1}$

Avrupa'da özellikle, 15. yüzyılda kendisini hissettiren gelişmeler, Osmanlı devletini de derinden etkilemiştir. Nitekim Avrupa'da feodal yapılar yerine millî monarşi denilen krallıkların kurulmaya başlanması, ordu düzenlerini de etkileyerek bir takım değişikliklere yol açmıştı. Zirâ

${ }^{1}$ Gabor Agoston, Barut, Top ve Tüfek: Osmanlı Imparatorluğu'nun Askeri Gücü ve Silah Sanayisi, Çev. Tanju Akad, İstanbul 2006, s. 28.

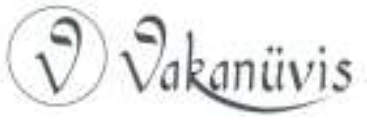


bu dönemde Avrupalıların büyük bir sistem değişikliğine giderek, ordularını Osmanlı ordusuna benzer daimi bir ordu şeklinde düzenlemeye başladıkları görülür. Aynı zamanda yeni silah teknolojisi ile keşfettikleri küçük taşınabilir ateşli silahların hızla dünyaya yayılmasıyla, artık savaşlarda ok, yay gibi konvansiyonel silahlar yerine ateşli silahlar kullanılmaya başlanmıştır. Parry'e göre Osmanlı dışındaki gelişmelerin en etkilisi bu silah teknolojisindeki değişikliklerdi. ${ }^{2}$ Buna rağmen Osmanlı devleti, ateşli silah teknolojisinin kullanımı hususunda neredeyse 18. yüzyılın başına kadar Avrupa'nın karşısında durabildi. Agoston'a göre bunun en önemli nedeni, devletin barut için gerekli hammaddeler açısından zengin olmasıydı. ${ }^{3}$

Osmanlı ordusunda bilhassa top kullanımı erken dönemlere rastlamaktadır. 16. yüzyıl sonlarına doğru orduda top kullanıldığı bilinmekle beraber topçuluk, Fatih Sultan Mehmed zamanında gelişme göstermiştir. Osmanlı toplarının tunç, demir ve bakır madenlerinden üretildiği bilinmektedir. ${ }^{4}$ İstanbul'un Galata tarafındaki Tophane mevkii, kapıkulu topçuları için yaptııılmış ve top yapmak için gerekli demir ise, Anadolu ve Balkanlardaki demir madenlerinden sağlamıştır. ${ }^{5}$ Osmanlı belgelerinde genellikle "Âhen-i hâm" olarak adlandırlan demir, Anadolu ve Balkanlarda bulunan demir madeni yataklarından çıkarılmaktaydı. Anadolu'da Maraş, Keban, Bilecik, Kiği, Divriği ve Develi'de Balkanlarda ise; Bulgaristan, Makedonya, Bosna ve Sırbistan'da demir yatakları

\footnotetext{
2 Vernon J. Parry, "Barut", The Encyclopaedia of İlam (EI2), I, Leiden 1986, s. 1062-1066.

${ }^{3}$ Agoston, a.g.e, s. 27-31; Diamond'un da belirttiği gibi, 10. yüzyıldan beri savaşlarda kullanılmaya başlanan ve teknolojik gelişmelerle birlikte yok edici bir hale gelen güherçile, kükürt ve odunkömürü karışımından oluşan barut, eski dönemlerdeki icatlarda olduğu gibi gözlem, deneme ve yanılma yoluyla keşfedilmiştir. Ayrıntı için bkz. Jared Diamond, Tüfek, Mikrop ve Çelik, Tübitak Popüler Bilim Kitapları, Ankara 2010, s. 316317.

${ }^{4} 16$. yüzyılın başlarında demircilerden oluşan topçu cemaatinin sayısı yaklaşık 25 kişiden oluşmaktaydı. Bu dönemde demircilerin bir hayli demir top döktükleri bilinmektedir. Ayrıntı için bkz. İdris Bostan, "16.yy. Başlarında Tophane-i Amire ve Top Döküm Faaliyetleri", Halil Inalcık Armağanı I, Ankara 2009, I, s. 253; Salim Aydüz, "Tophane-i Amire ve Osmanlılarda Top Dökümü", Osmanlı Askeri Tarihi, İstanbul Aralık 2011, s. 2154.

5 İsmail Hakkı Uzunçarşılı, Osmanlı Tarihi, C.2, Türk Tarih Kurumu Basımevi, Ankara 1988, s. $562-63$.
}

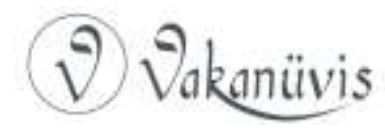


mevcuttu. Bosna'daki demir üretim merkezleri Kamengrad, Kreşova, Vareş Fojnica' da bulunmaktaydı. ${ }^{6}$

Osmanlı devleti madenlere verdiği önemden dolayı neredeyse kuruluş döneminden itibaren maden ocağı bulunan yerlerin ele geçirilmesinde ve işletilmesinde büyük bir titizlik göstermiştir. Bu bağlamda 15. yüzyılın ikinci yarısından sonra Balkanlarda bulunan bir çok maden sahasının da Osmanlı devletinin denetimine geçtiği ve bu maden sahalarının yeniden işletmeye açıldığı görülmektedir. Bilindiği gibi maden yatakları, malî bakımdan olduğu kadar askerî alanda da son derece önemliydi. Bu nedenle bakır, gümüş, altın, kurşun ve demir gibi stratejik açıdan önemli madenlerin ihracı yasaklanmıştı. ${ }^{7}$ Zirâ devletin 16. yüzyılın ilk yarısına kadar Anadolu ve Balkanlarda elde ettiği güçlü konumu, askerî başarılarına bağlıydı bu da mühimmatı güçlü bir orduyla sağlanmıştı. Bu nedenle ilk fetihlerden itibaren ele geçirilen yerlerdeki madenleri ve madenci reâyâyı korumak devletin öncelikleri arasında yer almıştı.

\section{Osmanlı Devletinde Maden Hukuku}

Bilindiği üzere maden, yer üstünde veya yer altında bulunan her çeşit cisim ve cevhere verilen addır. Osmanlı devletinin resmi dini İslam dini olması nedeniyle, maden hukukunda da İslam hukukuna uygun hükümlerin kullanıldığı görülmektedir. Fıkıh kitaplarında rikâz başlığı altında incelenen maden için şer’î hukukta şu hükümler yer almaktadır. Buna göre; maden bulunan araziler dört kısma ayrılmaktadır. Birincisi; herkesin yararlanabileceği metrûk arazilerdir. Bu tür arazilerde madenin beşte biri devlete geri kalanı ise bulana aittir. íkincisi; mîrî arazidir. Burada madenlerin tamamı devlete aittir, devlet tarafından işletilir veya işlettirilir. Üçüncüsü; mülk arazidir ki burada bulunan madenlerin beşte biri devlete kalanı ise sahibine aittir. Dördüncüsü ise; vakıf arazi olup bunun da beşte biri devlete geri kalanı da bulana aittir. Burada şu hususu da belirtmekte fayda var. İmam-ı a'zamın kamu otoritesinin onayı

\footnotetext{
${ }^{6}$ Mustafa Altunbay, "Klasik Dönemde Osmanlı' da Madencilik", Türkler, C.X, Ankara 2003, s. 796.

${ }^{7}$ S. Katić, I. Ilić and D. Živković, "Copper Productıon In Majdanpek In Sıxtıes And Seventıes Of The 16th Century", Journal of Mining and Metallurgy, 45 (2), 2009, s. 218; Fahrettin Tızlak, “Osmanlı Devleti'nde Madencilik”, Osmanlı, C.3, Yeni Türkiye Yayınları, İstanbul 1999, s. 312.
}

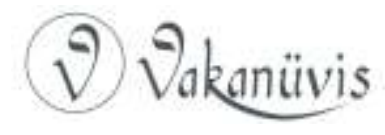


alınmadan doğal bir servetin işletilemeyeceğini ileri sürmesi ve bu görüşüne de "bir şahıs için devlet reisinin tasvibi olmadan, madenler hususunda meşrû hakka sahip olmadığı " hadisini delil olarak göstermesi, çoğunluğu mîrî arazide bulunan Osmanlı madenleri ile ilgili kanunnamelerin meşruiyet dayanağını oluşturmaktadır. ${ }^{8}$

Osmanlılar Sırbistan ve Bosna'da ele geçirdikleri madenlerin üretim yöntemlerinde ve terminolojisinde önemli bir değişiklik yapmayarak, bölgeye 13. yüzyılın ortalarında Sakson göçmenlerince getirilen Alman (Sakson) terminolojisini koruyarak tercüme etmişler ve kendi idarî örgütlenmelerini bunun üzerine yerleştirmişlerdir. ${ }^{9}$

Fatih ve II. Bayezid döneminde madenlerle ilgili kanunnamelerin çıkarıldığı bilinmektedir. Fatih dönemine ait yasakname ve kanunları ihtiva eden "Kânûn-nâme-i Sultânî ber-mûceb-i örf-i Osmânî" devletin farklı yerlerindeki maden ocakları ve buradan çıkarılan altın, gümüş, demir gibi değerli madenler hakkındaki kanunnameleri kapsamaktadır. ${ }^{10}$ Kanuni döneminde yine Alman kökenli bir maden kanunu, Osmanlı hukuk yapısına göre yeniden uyarlanarak yayınlanmıştır. ${ }^{11}$

Görüldüğü üzere devlet, büyük bir çoğunluğu kendisine ait olan madenlerin işletme usullerini ve konuyla ilgili hukûkî düzenlemeleri yaparken, İslama aykırı olmayan eski örf, adet ve hatta kanunlardan da yararlanmıştır. Çoğunluğu Fatih ve II. Bayezid döneminde hazırlanan bu kanunnamelerde, maden ocaklarında çalışanların yükümlülükleri,

\footnotetext{
8 Ahmet Akgündüz, Osmanlı Kanunnameleri ve Hukuki Tahlilleri, I. Kitap Osmanlı Hukukuna Giriş ve Fatih Kanunnameleri, Fey Vakfı, İstanbul 1990, s. 157-158; Neşet Çağatay, "Osmanlı İmparatorluğu'nda Maden İşletme Hukuku", Ankara Üniversitesi Dil Ve Tarih Coğrafya Fakültesi Dergisi, C.II, S.I, Ankara 1943, s. 119-120.

${ }^{9}$ Halil İnalcık, Osmanlı Imparatorluğunun Sosyal ve Ekonomik Tarihi 1300-1600, Çev. Halil Berktay, Eren Yayıncılık, İstanbul 2004, C.1, s. 96-97; 11. yüzyıl sonrası Orta Almanya'dan Sırbistan ve Bosna'ya göç eden madenci Saksonlar, mevcut ocakları ıslah ederek teknik ve hukukî açıdan Almanya ve Bohemya modeline uyarladılar, bu nedenle, Osmanlı kanunnamelerinde geçen teknik ve hukuki terimlerin birçoğu Almanca kaynaklı olup, Sırpça-Hırvatça gibi yerel diller vasıtasıyla Osmanlı'ya aktarılmıştır. Bkz. Altunbay, a.g.m, s. 792.

${ }^{10}$ Bkz. Halil İnacık-Robert Anhegger, Kânûnnâme-i Sultânî Ber Mûceb-i Örfî Osmânî, II. Mehmed ve II. Bayezid Devirlerine Ait Yasakname ve Kanunnameler, Türk Tarih Kurumu Yayınları, Ankara 1956.

${ }^{11}$ Bkz. Robert Anhegger, Beitraege zur Geschichte des Bergbaus im Osmanischen Reich I. Europaeische Türkei, İstanbul 1943.
}

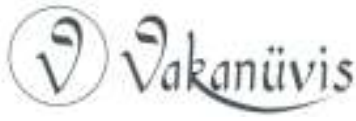


devletle olan ilişkileri ve madenin çıkarılmasından saklanmasına kadar bütün ayrıntılar yer almıştır. ${ }^{12}$

\section{Madenlerin İşletme Tarzları}

Osmanlı devletinde maden işletme hukuku, zaman ve mekâna göre değişmiş, yani devletin her yerinde ve her döneminde aynı işletme tarzı uygulanmamıştır. Madenin çeşidi, işletilmesindeki amaç, mahallî zaruretler ve devletin menfaatleri gözönüne alınarak, farklı işletme tarzları uygulanmıştır. Anadoludakiler için, Ergani, Keban, Gümüşhane, Rumelidekiler için Sidrekapsi, Kratova, Novo $\mathrm{Brdo}^{13}$ gibi eski madenlerin kuralları örnek alınmıştır. Bu bağlamda maden mukâta'aları şu üç tipte işletilmiştir. Birincisi; doğrudan doğruya devlet tarafından idâre ve işletme tarzı, ikincisi; devlet yardımı ve nezâreti altında, madenciler tarafından idâre ve işletme, üçüncüsü; iltizâm ya da malikâne üzere işletme tarzıydı. ${ }^{14}$

Klasik dönemin başlarında madenler çoğunlukla emanet yoluyla yani devlet tarafından atanan bir emin vasıtasıyla idare edilmiştir. Özellikle ilk zamanlarda gümüş, altın, bakır, kurşun ve demir gibi daha çok ticarî açıdan önemli olan madenlerin bulunduğu yerlere bir takım yetkilerle donatılan "Emin veya Nâzır" adı verilen bir yönetici ile bunların beraberinde birer katip ve tartıcı gönderilirdi. Salâh ve iffet ehlinden ve diyânet ve emânet erbâbından seçilen bu emin ya da nâzırlar, kâdının denetiminde görevlerini yaparlardı. Nitekim madenler hakkında yazılan hükümlerin çoğunda maden amiriyle birlikte o yerin kâdısına da hitap edildiği görülmektedir. Emin'e madenin büyüklüğüne ve önemine göre genellikle yakın bir mukâta'anın tahsil edilmesi kolay bir gelirinden havale edilebilen sermaye akçesi verilirdi. $O$ da kendisine verilen

\footnotetext{
12 Bkz. Akgündüz, a.g.e; Akgündüz, Osmanlı Kanunnameleri ve Hukuki Tahlilleri, Il. Kitap II. Bayezid Devri Kanunnameleri, Fey Vakfı, İstanbul 1990; Altunbay, a.g.m, s. 792.

13 Vulçitrin sancağının önemli bir kazâsı olan Novo Brdo, Osmanlı belgelerinde farklı şekillerde okunmaktadır. Novebri, Nevâbir gibi okunuş şekilleri olan bu yerleşim merkezinin asıl adı, Novo Brdo'dur. Gümüş madenleri nedeniyle Osmanlı devletini yakından ilgilendirmiş ve buraya özel 4 kanunname hazırlanmıştır. Akgündüz, a.g.e, I. Kitap, s. 553; Ahmed Refik'in eserinde geçtiği üzere, Rumeli'de en önemli gümüş, bakır ve demir ocakları; Novo Brdo, Serberniçe, Kıratova, Sidre Kapısı, Rudnik, Kamengrad, Koçanya ve Taşöz'de bulunuyordu. Ayrıntı için bkz. Ahmed Refik, Osmanlı Devrinde Türkiye Madenleri, Enderun Kitabevi, İstanbul 1989, s.V; Uzunçarşılı, a.g.e, C.2, s. 418.

${ }^{14}$ Çağatay, a.g.m, s. 122-126.
}

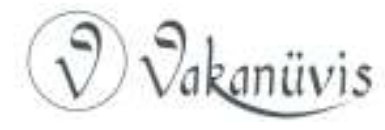


sermayeyi odun, kömür alımı ile madencilerin yiyeceklerini ve diğer malzemelerini teminde kullanırdı. Yıl sonunda ise elde edilen ürün ile verilen sermayenin muhasebesi yapılarak, işletilen madenin kâr ve zarar durumu ortaya çıkarılırdı. Devlet bu şekilde hazineye ait vergi gelirlerini, yine kendisinin atadığı maaşlı bir memuru vasıtasıyla tahsil etmiş olurdu. ${ }^{15}$

Rumeli'de madenciliğin gelişme göstermesiyle birlikte, Kanuni döneminde "Kânûn-ı ibâret-i Me'âdin" adıyla yeni bir mevzuat çıkarılarak, müteşebbislerin önünün açılması ve mültezimlerin ilgisinin maden sahalarına çekilmesi amaçlanmıştır. ${ }^{16} \mathrm{Bu}$ bağlamda Üsküp Nezâreti'ne bağlı Novo Brdo demir madenlerinin 1585 tarihinde iltizâma verildiği görülmektedir. ${ }^{17}$ Ancak burada şu hususu belirtmekte fayda var, maden mukâta'aları her ne şekilde işletilirse işletilsin, daima devletin denetimine açık olmuştur.

\section{Balkanlarda Bir Maden Ocağı: Kamengrad Demir Madeni}

Balkanların fethinden sonra atıl olan madenlerde gerekli düzenlemeleri yaparak tekrar işletmeye açmıştır. Özellikle altın ve

\footnotetext{
15 Çağatay, a.g.m, s. 124-126; Osmanlı Devleti'nde madenlerin başlangıçtan neredeyse 18. yüzyılın ilk yarısına değin emânet usulüyle yönetildiği bilinmektedir. Özellikle Amerikan gümüşünün yayılması ve üretim maliyetlerinin yüksek olması nedeniyle pek çok madenin kapandığı ve 18. yüzyılda tekrar açıldıkları görülmektedir. Devlet, maden ocaklarını atıl bırakmak ya da terk etmek yerine, işletmek istediği maden ocağına bir memurunu göndererek emâneten yönetim sistemini tercih etmiştir. Ayrıntı için bkz. Hasan Yüksel, Osmanlı Döneminde Keban-Ergani Madenleri 1776-1794 Tarihli Maden Emini Defteri, Sivas 1997, s. IX-XIII; Erol Özvar, Osmanlı Mâliyesinde Mâlikâne Uygulaması, Kitabevi, İstanbul 2003 s. 2-3; Ahmet Tabakoğlu, Gerileme Dönemine Girerken Osmanlı Maliyesi, Dergah Yayınları, İstanbul 1985, s. 128; Özer Ergenç, 16. Yüzyılın Sonlarında Bursa, Türk Tarih Kurumu, Ankara 2006, s. 157; Hülya Taş, XVII. Yüzyılda Ankara, Türk Tarih Kurumu, Ankara 2006, s. 45-52.

16 Mustafa Altunbay, Osmanlı Döneminde Bir Maden Işsletmesinin Tarihi Süreci: Sidrekapsi, İstanbul Üniversitesi Sosyal Bilimler Enstitüsü, Yayımlanmamış Doktora Tezi, İstanbul 2010, s. 20.

17 “.......̈̈sküp mukâta'âtı müfettişi Üsküp kâdısı mevlânâ Abdülkadir dâ'ileri 'arz gönderüb mahmiyye-i Üsküp'de sâkin el-hâcc Salih nâm kimesne bu dâ'ilerine gelüb Üsküp nezâretine tabi' Novo Brdo ma'denlerinin işçi hâsılları nısf-ı bad-ı hevâsı ve ma'den-âhen mukâta'ası sene 993 Zî́l-hiccesi 9'undan altı yıla 80 bin akçe mültezim olan....ve emîni Ahmed'in tahvîl-i evvelisi sene 996 Zî'l-hiccesi 8'inde tamâm olub....." BOA (Devlet Arşivleri Başkanlığı Osmanlı Arşivi) Maden Mukataası Kalemi Defterleri, (BOA. D.MMK.d), 22697, 9 Zî́l-hicce 996/30 Ekim 1588.
}

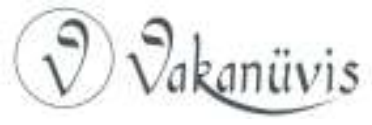


gümüş bakımından zengin olan madenler devletin gelir kaynaklarını artırıp, nakit para ihtiyacını karşılayacağı için bu gibi madenlerle yakından ilgilenildiği görülmektedir. Bu bağlamda değerli madenler ve uluslararası ticaretteki gümrük vergileri, devlet politikasının ilk hedefleri arasında olmuş ve devletin ilk dönemlerinden itibaren Balkanlardaki değerli maden sahaları üzerinde kontrol sağlamak için rakipleriyle sıkı bir rekabet içine girmişlerdir. ${ }^{18}$

Osmanlı devletinin Balkan fetihleri başladığında, Balkan yarımadasının batısında yer alan Bosna, Macarların hakimiyetinde yarı müstakil bir krallıktı. Sultan I. Murad'ın Rumeliye geçmeden önce Makedonya taraflarında harekâta geçerek, 14. yüzyılın sonlarında Arnavutluk ve Bosna taraflarına akınlar yaptığı bilinmektedir. 15. yüzyıl başlarında Bosna'nın iç işlerinin iyice karışması ve Macarların Bosna'ya karşı düşmanca davranışları, Bosna kralını Osmanlı devletine yaklaştırmış ve Macarlarla mücadele edebilmek için onlardan yardım istemişlerdir. Osmanlı devleti bu sayede Bosna'nın iç işlerine müdahale etmeye başlamış ve nihayetinde 1463 tarihinde Fatih Sultan Mehmed tarafından fethedilen Bosna, Rumeli beylerbeyine bağı bir Osmanlı sancağı haline getirilerek Osmanlı devletinin batıya doğru genişleme siyasetinde bir uç bölgesi niteliğinde olmuştur. Aynı tarihte Kamengrad'ı da ele geçiren Osmanlılar, kaleye askerlerini yerleştirerek kale ve etrafının asayişini sağlamaya çalışmışlardır. ${ }^{19}$ Hemen ardından Venediklilerin Mora'da, Macarların ise Bosna'da Türkleri çıkarmaya teşebbüs etmeleri ve hatta bazı kaleleri geri almaları, 1464 tarihinde Bosna'ya ikinci bir sefer düzenlenmesine neden olmuş ve daha önce alınamayan bazı önemli kaleler de bu sefer sırasında ele geçirilerek, Venediklilere ve Habsburglara karşı önemli bir üs bölgesi rolünü üstlenmişlerdir. ${ }^{20}$

Balkanlarda bilhassa Kratova, zengin gümüş yatakları ile tanınmıştı. Şöyle ki; Kosova (Vulçitrin, Novaberde, Priştine, Yanova, Tırgovişte,

18 İnalcık, Osmanlı İmparatorluğu'nun............ , s. 96-97; Ömerül Faruk Bölükbaşı, 18. Yüzyılın İkinci Yarısında Darphâne-i Amire, İstanbul Bilgi Üniversitesi Yayınları, İstanbul 2013, s. 76.

19 Uzunçarşılı, Osmanlı Tarihi, C.1, Türk Tarih Kurumu Basımevi, Ankara 1988, s. 162-220; Hatice Oruç, "15. Yüzyılda Bosna Sancağı ve İarî Dağılımı", Ankara Üniversitesi Osmanlı Tarihi Araştırma ve Uygulama Merkezi Dergisi (OTAM), 18/2005, Ankara 2006, s. 250. ${ }^{20}$ Uzunçarşılı, a.g.e, C.2, s. 81-84.

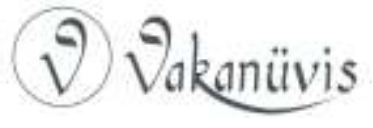


Trepçe ve Belasniçe), Makedonya (Kratova, Koçana, Kumanova İvraniye, İştib, Radovişte ve Eğridere), Sırbistan (Bırvenik, Koznik, Zaplana ve Ürgüb) ve Bulgaristan (Köstendil) sınırları içerisinde maden yatakları bulunmaktaydı. ${ }^{21}$ Altunbay'da makalesinde aynı bölgelerin 15 ve 18. yüzyıllarda maden yatağı olma özelliğinin altını çizmektedir. ${ }^{22}$

Nitekim Fatih zamanında hazırlanan Üsküp'le ilgili hukukî düzenlemelerin tamamı, Üsküp sancağına bağlı ve Üsküp'ün güneydoğusunda bulunan Kratova kazasındaki maden yatakları ile ilgilidir. Devletin yine Balkanlarda Novo Brdo, Trebçe ve Selanik sancağına bağlı Sidrekapsi ${ }^{23}$ kazalarındaki gümüş madenlerinden de istifade ettiği bilinmektedir. ${ }^{24}$

Bu bağlamda Balkanlarda stratejik bir konuma sahip olan Bosna önemli ve zengin bir maden bölgesiydi. Altın ve gümüş maden yataklarının yanında bölgenin hemen hemen her yerinde demir madenleri mevcuttu. ${ }^{25}$ Bilhassa Bosna'nın batı bölgesi demir üretimi açısından önemliydi. İşte bu demir yataklarından birisi de Kamengrad'ta bulunmaktadır. ${ }^{26}$ Önceleri sancak beyinin hâssına dahil edilen

\footnotetext{
${ }^{21}$ Eyüp Kul, "1703 Tarihli Bir Rapora Göre Kratova, Köstendil, Üsküp, Trepçe ve Jejene Madenlerinin Islahı", Belleten, C. LXXX, S.288, Ankara 2016, s. 396.

${ }^{22}$ Altunbay, a.g.m, s. 796.

${ }^{23}$ Sidrekapsi madenleri 15. yüzyılın ikinci yarısından sonra uygun biçimde nizam verilerek işletime açılmıştır. Sidrekapsi madenleri ile tanınan bir kaza olup, en önemli geçim kaynağı da madenciliktir. Ayrıntı için bkz. Altunbay, a.g.t, s. 16.

24 Uzunçarşılı, a.g.e, C.2, s. 15, 683; BOA. (Devlet Arşivleri Başkanlığı Osmanlı Arşivi) ibnülemin Me'âdin, (BOA.IE.MDN), 1/1, 29 Zî'l-hicce 904/8 Temmuz 1499; "Kratova ma'deninden hariç ve Vulçitrin sancağında Terbiçe'de vâki' merhûm İbrahim Paşa işletdirdiği kuyu cevher fırtına olmağla varılub 'akd-i meclis olundukda ....ihtiyârlardan evvel kuyu işlediği zamânda mevcûd olanlardan Vulçitrin kasabası sâkinlerinden Ya'kub Ağa ve Kato Mustafa Çelebi ve Emrullah Efendi ve Paşu Efendi ve Ahmed Ağa ve Terbiçe sakinlerinden .....nâm zımmîden sû'âl olundukda zikr olunan kuyu 1100 târîhinde vâki' istîlâya değin işler ve içinde cevher çıkar ve vâfir cevheri var idi ...."Bkz. Refik, a.g.e, s. 5051.

25 Şemsettin Sami, Kâmûsü'l-alâm, İstanbul, 1308, s. 1386; Bosna sancağının en önemli merkezlerinden biri olan Serebriniç, Bosna'nın en önemli gümüş maden yataklarındandır. Bosna sancağı ile ilgili tek hukukî düzenleme, Serebriniç Maden Yasaknâmesidir. Serebriniç'de bulunan madenler mîrîye ait olduğundan ve havâss-ı hümâyûn kabul edilerek varidatı doğrudan devlet hazinesine aktarılmaktadır. Bkz. Akgündüz, a.g.e, I. Kitap, s. 480.

${ }^{26}$ Refik, a.g.e, s. 16; Kığı, Samako (Sofya), Bilecik, Kamengrad (Bosna) Osmanlı devletinin demir çıkarılan maden ocaklarındandı. Bkz. Ahmet Tabakoğlu; Türk iktisat Tarihi, Dergah
}

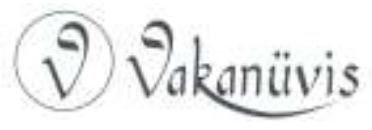


Kamengrad, Sana nehri kıyılarından başlayarak Klyuç’a kadar günümüz Priyedor bölgesini ve kuzeyde Vrbas nehri ve Gonyenitsa, Priyeka ve Dragoçay nehirlerini içine alan bir yerleşim birimidir. Burada yaşayan nüfusa madencilikle ilgili görevlerin verildiği görülmektedir. Ancak bölge halkının bu durumdan rahatsız olması üzerine, Kamengrad'a Yeni Pazar'dan kömürcüler, çukur kazıcılar ve top güllesi imal eden ustalar sevk edilmiştir. ${ }^{27}$ Bosna'nın batı kısmında bulunan Banaluka'nın 1527 tarihinde ele geçirilmesiyle, bu bölgede bulunan madenler de Osmanlı Devleti'nin denetime geçmiştir. ${ }^{28}$

Kamengrad ile Klis sancağına ${ }^{29}$ tabi Güllüce kaleleri yakınında bir demir madeninin ortaya çıktığı 3 Cemâziyye'l-âhir 979/16 Ekim 1571 tarihli topçu başına yazılan bir hükümden anlaşılmaktadır. Belgede merkezden bu madenlerde top dökmek üzere usta hassa dökmecilerinden beş kişinin talep edilmesi madenin verimli olduğunu

Yayınları, İstanbul 1998, s. 227; Fabijan Trubelja- Ljudevit Baric, Minerals of Bosnia and Herzegovina, Sarajeva 2011, s. 19.

${ }^{27}$ Adem Handžić, "Rudnici U Bosni Od Druge Polovine XV do Početka XVII St.", Prilozi, LXXIX, Sarajevo 1987, s. 355-356.

28 Banaluka, Mohaç zaferinden hemen sonra Yayça bölgesinin alınmasının ardından 1527-1528 tarihinde ele geçirilmiştir. Şehir küçük bir kale, dış yerleşme yeri ve kaplıcadan ibaret iken özellikle 16. yüzyılın ikinci yarısından başlayarak Osmanlı hakimiyeti altında hızla gelişerek aşağı doğru yayılmıştır. 1540 tarihinde Bosna sancağına bağlı müstakil bir nahiye olarak görünmektedir. Mohaç zaferiyle fethedilen yerler, önce Neretva kazasına daha sonra da yeni oluşturulan Kobaş kazasına bağlanmıştır. Bu bağlamda Kamengrad da ilk başlarda Neretva kazasına tabi iken, 1550 tarihinde Kobaş kazasına bağlı bir nahiye konumundadır. 16. yüzyılın ikinci yarısında ise Kobaş kazasının merkezinin Banaluka'ya taşındığı görülmektedir. Bkz. Feridun Emecen, "Banaluka" Türk Diyanet Vakfı İs/âm Ansiklopedisi (DIA), C.V (1992), s. 49-51; Oruç, "Administrative Division of the Bosnian, s. 117-133; 15. yüzyılda Kral vilayetinde Bobovac ve Neretva olmak üzere iki kadılık vardı.16. yüzyılda bazı nahiyeler birleştirilerek, 1516 tarihinde Neretva kazası oluşturuldu. 1537 tarihinde ise Klis sancağına bağlanan Neretva kazasının adına 1550 tahririnde rastlanmamaktadır. Ayrıntı için bkz. Oruç, "Administrative Division of the Bosnian Sandjak in the 16 th Century", Ankara Üniversitesi Osmanlı Tarihi Araştırma ve Uygulama Merkezi Dergisi (OTAM), 25/Bahar 2009, Ankara, s. 121.

${ }^{29}$ Klis sancağı 1537 tarihinde oluşturulmuştur. Bkz. Oruç, "Administrative Division of the Bosnian ....", s. 106-107; Gazi Hüsrev Beğ'in arkadaşı ve ortağı olan ilk Klis sancak beyi Murat Bey, 1537 'de Klis'in fethinde önemli rol oynamış ve 1543 tarihine kadar bu görevde kalmıştır. Bkz.Fazileta Hafizović," Posjedi zvaničnika ı njihovih porodica u Kliškom Sandžaku u XVI stoljeću." Znakovi vremena-Časopis za filozofiju, religiju, znanost $i$ društvenu praksu 48-49 (2010), s. 228-257.

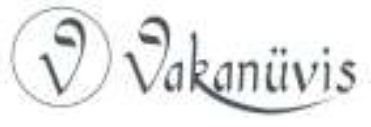


düşündürmektedir. ${ }^{30}$ Bir başka belgede ise, bu madenlere hizmet için birkaç köy halkının görevlendirilmesi ve bunların muaf oldukları vergiler ile isimlerinin merkeze gönderilmesi belirtilmiştir. ${ }^{31}$ Görüldüğü üzere devlet, madenlerde hemen üretime geçmeyi istemiştir. Zirâ askerî açıdan hareketli olan bu bölgede bilhassa etraftaki kalelerinin ve aynı zamanda ordunun top mermisi ve gülle ihtiyacının acilen temin edilmesi gerekiyordu.

Yine Semendire mukata'ası nâzırına ve Bâc eminine yazılan bir hükümde ise, Bosna sancağına tabi Kamengrad yakınlarında top yuvalağı dökmeye uygun "küffâr zamanından" kalma, hala işe yarar bir madenin varlığından söz edilip, bu madeni işletmek için Zaim Osman ile merkezden Mehmed Çavuş'un görevlendirildiği bildirilmiştir. Ayrıca Bosna beyine madene iş̧̧i ve mühimmat talep ettiği zaman hemen göndermeleri de emredildiği ve madeni işletmek üzere kendisine zeâmet verilen ehl-i vukûftan Osman ve merkezden gönderilen topçu bölük başılarından Mehmed'in yeterli sayıda cerahor ${ }^{32}$ ile madene geldiği ve madenin artık işlemeye başlayacağı anlaşılmaktadır. ${ }^{33}$ Belgelerden de takip edildiği üzere devlet, varlı̆̆ı Osmanlı öncesinde de

30 BOA. (Devlet Arşivleri Başkanlığı Osmanlı Arşivi) Divân-ı Hümâyûn Mühimme Defterleri, (BOA. A.DVNSMHM.d), 16/127, 3 Cemâziyye'l-âhir/23 Ekim 1571.

${ }^{31}$ BOA. A.DVNSMHM.d, 16/47, 26 Cemâziyye'l-evvel 16 Ekim 1571.

32 Cerahorlar, ücretleri avarız haneleri tarafından, tekâlif-i divâniye vergisi yerine sayılmak üzere, sırf sefer zamanlarında tutulan adamlar olup, vazifeleri ordunun geri hizmetlerini görmekten ibaretti. Bkz. Mustafa Akdağ, Türkiye'nin iktisâdî ve içtimâî Tarihi, Tekin Yayınevi, Ankara 1979, s. 426.

33 BOA. A.DVNSMHM.d, 19/82, 13 Muharrem 980/26 Mayıs 1572; "......gâyet a'lâ ve güzîde ma'dendir ve işletdirüb ol yerin ehl-i vukûfundan 'Osmân nâm kimesne kendüye ze'âmet olmak üzere 'uhdesine aldığın bildirüb ve demirin numûnesini dahi gönderüb gayet a'lâ demir olmağın zikr olunan ma'den işletdirilmke emrim olub mezbûr 'Osmân'a şartı üzere ze'âmete emrim verilüb ma'den-i mezbûru işletdirmek içün dergâh-ı mu'allâm topçuları bölük başılarından Mehmed ta'yîn ve irsâl olunub ve ma'dene lazım olan işçi ve dökücü, ve dersha, ve kalıb ve kazma ve kürek ve sâ'ir alâtdan her ne lâzım ise bî-kusûr irsâl etmek içün Semendire mukâta'âtı nâzırına ve Bâc ma'deni emînine hüküm gönderilmiştir ve 'avârız-ı divâniyye ve tekâlif-i 'örfiyyeden mu'âf olmak üzere ol ma' dene hıdmet edecek ne mikdâr kurâ halkı kifâyet ederse ve kangıları ihtiyâr ederlerse evkât-ı vechile görülüb......" BOA. A.DVNSMHM.d, 19/80, 13 Muharrem 980/26 Mayıs 1572; Arif Bilgin-Ümit Ekin, "Bir Kimliğin Dönüşümü: "Asker"likten "Asker-Esnaf"lığa", Akademik Incelemeler Dergisi, 2007, 2.1, s. 220.

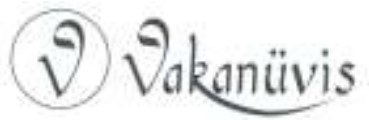


bilinen bu maden ocağını, merkezden görevlendirdiği emini aracılığı ile işletmeyi hedeflemiştir.

Devletin en önemli gelir kaynakları arasında yer alan madenler, aynı zamanda maden erbabı adı altında geniş bir grubu da ifade etmekteydi. Şöyle ki H. 967/M.1560 tarihlerinde küçük ölçekli bir demir madeni olan Bilecik'te bile 6000 bine yakın işçi çalışmaktaydı. Maden erbabına bölgedeki halk da dahil edilmişti. Bunlar, madene odun, kömür, yiyecek ve diğer zaruri ihtiyaçların taşınmasında ve aynı zamanda ham ve işlenmiş madenlerin naklinde görevlendirilmişlerdi. Diğer taraftan maden işinde görevlendirildiklerinde madencilere uygulanan hükümlere tabi olan yaya, yörük, mütekaid sipahizadeler gibi askeri teşkilata bağlı gruplar da düşünüldüğünde maden erbabı geniş bir nüfusu ifade etmekteydi. ${ }^{34}$

Maden ocaklarına büyük önem veren devlet, burada çalışacak olan için de gerekli hukukî düzenlemeleri yapmıştır. Nitekim madenciyân reâyâsı olarak adlandırdığı bu sınıfa yönelik bir muafiyet sistemi geliştirerek, onları devlet kontrolü altında muhtelif hizmetleri yerine getirmekle yükümlü tutmuştur. Madenlerde çalıştırılacak işçilerin seçiminde ise, genellikle maden ocağına yakın çevreden olmalarına ve bilhassa bu işte ehil olanların tercih edilmesine dikkat edilmiştir. Aynı zamanda madenci reâyâ normal reâyâdan ayrı tutularak, devlet tarafından atanan eminleri dışında diğer devlet görevlilerinin madenci reâyâsına karışmaları da kanunen yasaklanmıştır. ${ }^{35}$

$\mathrm{Bu}$ bağlamda Kamengrad madenini işleten Zaim Osman merkeze gönderdiği dilekçede, ne kadar fazla top yuvalağı ve darbzen ${ }^{36}$ fındığı işlerse, hem etraftaki kalelere hem de hazineye yararı olacağını bildirerek, madenin çevresindeki bazı havâss-ı hümâyun köylerinin madene bağlanmasını talep etmesi üzerine, çevredeki 12 köyün madene bağlandığı görülmektedir. Ayrıca maden hizmetine atanan reâyânın işini inmal etmemesi, reâyâya havâss-ı hümâyun eminleri ve sancak beyleri

\footnotetext{
${ }^{34}$ Çağatay, a.g.m, s. 117.

35 Bkz. Altunbay, a.g.m, s. 793-794.

36 Darbzen, zarbzen veya zarbuzan adı verilen silahlar Osmanlıların seferlerinde en çok kullandıkları toplardı. Kelime olarak dövücü top anlamına gelmesine rağmen, bu hafif toplar sahra topu olarak muharebelerde de kullanıldığı bilinmektedir. Bkz. Agoston, a.g.e.s. $117-119$.
}

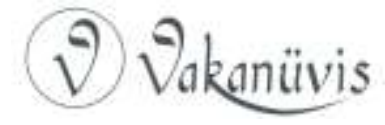


tarafından müdahale edilerek üretimin geciktirilmemesi, herhangi bir zorlukta işlerin imece usulüyle tamamlanması da sıkı bir şekilde tenbih edilmiştir. ${ }^{37} 17$ Receb 981/12 Kasım 1573 tarihli Bosna beyine ve kadısına gönderilen hükümde ise, Yeni Pazar'ın madene uzak olduğuna dikkat çekilerek, madene yakın yerlerden işçi getirtilmesi aksi takdirde üretimin aksayacağı ifade edilmiştir. ${ }^{38}$ Devlet bu şekilde madenlerde üretimin aksamadan devam etmesi için hem bölge idarecilerini hem de madeni yönetenleri uyarmıştır.

Madende bazen etraftaki kalelerde bulunan ve ordunun geri hizmetlerinde kullanılan grupların da görevlendirildikleri görülmektedir. Ancak bu gruplarla ilgili zaman zaman sorunların da yaşandığı bilinmektedir. Örneğin Kamengrad madeninin işletmeye açıldığı ilk dönemlerde Kamengrad kalesinin muhafazasında görevli olan Eflak taifesinin $^{39}$ madende çalışmak üzere görevlendirildiği ancak bunların madende çalışmak istemeyerek kaçtıkları, merkezden Bosna beyine yazılan bir hükümden anlaşılmaktadır. Belgede, sınıra yakın olan Kamengrad kalesindeki Eflak taifesine herhangi bir düşman saldırısında yolların ve geçitlerin muhafazası için ihtiyaç duyulacağı bu nedenle madende çalışmak istemeyen Eflakların kaleden kaçtıkları takdirde sınır bölgesinin savunması kalacağı belirtilerek, madendeki işçi sorununa başka bir çözüm bulunması ifade edilmiştir. Yine aynı belgede su

\footnotetext{
37 “.......havâss-ı hümâyûnum emînlerinden ve sancak beği olanlardan ve gayriden kimesneyi dahl ü ta'arruz etdirmeyesiz ki ma'den- mezbûr 'avk olmak lâzım gelmeye anun gibi bir zarûret ve müzâyaka lâzım gelüb ihtîyâc olursa imece tarîkiyle görüb itmâmI maslahat etmek bâbında envâ' ikdâm ve ihtimâm eyleyesiz..." BOA. A.DVNSMHM.d, 10/300, 29 Zî́l-ka'de 979/13 Nisan 1572; “.... ma'den- mezbûre hıdmet için ta'yîn olunan kurâ ahâlisinden kimesneye ihmâl ve müsâhele etdirmeyüb emr olunan hıdmetlere mübâşeret etdirüb...."BOA. A.DVNSMHM.d, 10/301, 29 Zî́l-ka'de 979/13 Nisan 1572; BOA. A.DVNSMHM.d, 10/302, 29 Zî́l-ka'de 979/13 Nisan 1572.

38 BOA. A.DVNSMHM.d, 23/243, 17 Receb 981/12 Kasım 1573.

39 Hersek ve etrafında bulunan Eflaklarla ilgili ilk yazılı kanun Fatih Sultan Mehmed zamanında hazırlanmıştır. Eflâkan taifesi olarak bilinen bu grup, Karadağ ve Romanya bölgesi başta olmak üzere, bütün sınır boylarında oturan Ulah-Eflâk diye de bilinen bir sosyal sınıfı ifade etmektedir. Gayrimüslim olan Eflâklar, sefer zamanlarında ordunun geri hizmetlerinde görev alırken, diğer zamanlarda kale ve köprü tamiri gibi işlerlerle meşgul olurlardı. Bkz. Akgündüz, a.g.e, Kitap I, s. 494.
}

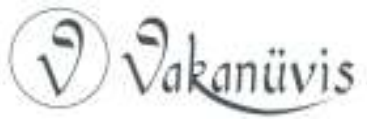


çarhlarını ${ }^{40}$ çalıştıracak yeterli miktarda su olmadığı için, çarhların eskiden beri işçiler tarafından çekilerek çalıştırıldığı ve buna çözüm olarak da "suya karîb çarh olmaya münasib yerde kifâyet mikdârı yuvalak işletmek için ma'den zuhûra getürmek emr edüb" ifadesinden suya yakın bir maden bulup işlettirmek gerektiği anlaşılmaktadır. ${ }^{41}$

Bu doğrultuda 17 Receb 981/12 Kasım 1573 tarihli bir hükümde, Kamengrad kazasında ortaya çıkan demir madeninin "gayet a'lâ yer olub cevheri, çarhları ve suları ve odunu yerli yerinde olub her ahvâli murâd üzeredir" şeklinde geçen ifadeden su sorununun, ya Kamengrad'ta suya yakın yeni bir maden bulunarak ya da başka bir şekilde çözüldüğü tahmin edilmektedir. ${ }^{42}$

Belgelerden de takip edildiği üzere, Kamengrad'ta bulunan demir madeninin organizasyonu yaklaşık iki yıl kadar bir zaman almıştır. Madenin yönetimine bu işi bilen kişilerin atanmasına dikkat edilmiş ve Bosna beğine, Kamengrad ve Banaluka kadılarına yazılan hükümlerde merkezden gönderilen eminlere her türlü yardımın yapılması tembihlenmiştir. Şöyle ki; eminlerin madeni işlemek için gerekli olan "cerahor, pirimikür"43 ve madene ait diğer hususlardaki yardım taleplerinin hemen yerine getirilmesi emredilmiştir. ${ }^{44}$ Nitekim madenin tam kapasite çalışarak top mermisi ve güllesi üretebilmesi, bu görevlilerin ve diğer ihtiyaçların sorunsuz bir şekilde madene ulaşmasına bağlıydı. Böylece devlet olası bir savaş durumunda topçuların mühimmatını hazır etmiş olacaktı. Bu nedenle maden çıkarılan yerlerin

\footnotetext{
40 Çarh, madenin kuyudan çıktıktan sonra işlem gördüğü yerdi. Su çarhı ve kuru dolap çarhı olmak üzer iki çeşit çarh vardı. Kuru dolap çarhını bargirler çekerlerdi. Diğerinde ise su kaynağının yakınlarda olması önemliydi. Bkz. Akgündüz, a.g.e, I. Kitap, s. 162-163. 41 “......Kamengrad kal'ası kurbunda küffâr zamânından kalmış top yuvalağı dökmeğe kâbil demir ma'deni husûsu tefahhus olunub zikr olunan mevzi'de demir ma'deni vardır lakin demir çarhları yapılmağa su gayet sa'b ve ba'îd bir yerde olub iki ay mikdârı biner ikişer bin cerahor hıdmet eyleyeler sular çarhları yapılacak yere gelmez küffâr zamânından dahi su çarhı yapılmağa imkân olmadığı ecilden ademlere çarh çektirirlermiş deyu......" BOA. A.DVNSMHM.d, 19/636, 19 Receb 980/17 Ağustos 1572.

42 BOA. A.DVNSMHM.d. 23/243, 17 Receb 981/12 Kasım 1573.

${ }^{43}$ Elli hane şeklinde teşkilatlandırılan Eflâk taifesinin nahiye kethüdalarına Knez, köy kethüdalarına da Pirimikür adı verilirdi. Bkz. Akgündüz, a.g.e, I. Kitap, s. 494.

44 “....ma'dene müte'allik husûslarda mu'âvenet taleb eyledikde her husûsda mu'âvenet ve müzâheret eyleyüb vâfir ve müstefî yuvalak işlemek bâbında envâ' sa'y ve ikdâmın...."BOA. A.DVNSMHM.d, 23/333, 28 Receb 981/23 Kasım 1573.
}




yöneticilerine sürekli emirler gönderilerek, üretimin artması için kömürcü, kuyucu, usta, topçu ve yörüklerin zamanında gönderilmesi istenmiştir. Ancak buna rağmen 22 Cemaziyye'l-âhir 982/9 Ekim 1574 tarihli bir belgede kömürcü ve kuyucunun madene zamanında gelmediği için yörüklerle ancak 1100 adet yuvalağın dökülebildiği, kuyucu, kömürcü ve diğer ustaların vaktinde gelmeleri halinde daha fazla yuvalağın yapılabileceği ifade edilmiştir. ${ }^{45}$

Madenlerde çalışanların genellikle ocakların çevresinden seçilmesine dikkat edilse de ocağın çok verimli olması durumunda farklı yerlerden de istihdama ihtiyaç duyulmuştur. ${ }^{46}$ Örneğin çingene taifesi, tekâlif-i örfiyye ve avârız-ı divâniyye gibi vergilerden muaf tutularak madende çalışmak üzere görevlendirilmiş ve aynı zamanda uzaktan gelen reâyâya nafaka verilmesinin de uygun olacağı belirtilmiştir. ${ }^{47}$

Maden ocaklarının faaliyetine, korunmasına, yollarda güvenli bir şekilde gidip gelmelerine son derece dikkat edilmiştir. Bu bağlamda madende işlerin aksamadan yürümesi ve madenin verimli olması gibi durumlarda yörüklerin de madenlerde istihdam edildiği görülmektedir. Özellikle eşkiya saldırılarını önlemek için maden ocağı olan bölgeye kuvvetli bir idareci atandığı gibi bir de madenlerin etrafına aşiretler iskân ettirilmiştir. Bilhassa Balkanlarda sıkça eşkiyanın saldırısına uğrayan madenlere, ordunun geri hizmetinde kullanılan derbentçiler, martoloslar, yayalar ve yörükler yerleştirilmiştir. Nitekim 16. yüzyıl sonlarında Bâc madeninde çalışan madencileri ve oduncuları eşkiyadan korumak için yaklaşık 80 martolosun görevlendirildiği bilinmektedir. ${ }^{48}$

45 “......zikr olunan ma'den işledilmesine gereği gibi mukayyed olub kuyucu ve kömürcüleri vakt ile tedârik edüb inşallah hemen nevrûzda işletmeğe mübâşeret edesiz ve topçu ve üstâdlar ve yörükler bu cânibden zamânında getirilmek......" BOA. A.DVNSMHM.d, 26/744, 22 Cemâziyye'l-âhir 982/9 Ekim 1574; Bir yılda 13-14 okka ağırlığında 1100 adet gülle imal edildiğinden ve gülle başına 4 akçe düştüğünden bahsedilmektedir. Bkz. Handžić, a.g.m, s. 356.

${ }^{46}$ Çağatay, a.g.m, s. 117.

${ }^{47}$ BOA. A.DVNSMHM.d, 23/306, 28 Receb 981/23 Kasım 1573;“...; Eminleri dışında ehli örf taifesinin reâyâya karışmaması tenbihlenmiş, ancak madende cevher tükenir ya da malî nedenlerden dolayı statülerinin normal reâyâya dönebileceği belirtilmiştir. Ayrıntı için bkz. Altunbay, a.g.m, s. 793-794.

48 Ahmet Refik, a.g.e, s. Vl; Altunbay, a.g.m, s. 792; "Geri hizmet kıtaları olarak adlandırılan derbentçi, menzilci, yörük, tatar, müsellem, cerahor, cambaz, lağımcı gibi

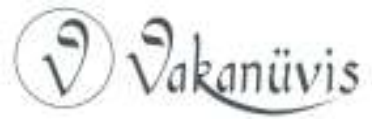


Madende çalışmak veya madeni korumak üzere yerleştirilen bu gruplar, nöbet sistemine göre çalışırlardı. Genellikle seferberlik zamanlarında ocakların tam kapasite çalışabilmeleri için görevlendirilirlerdi. Bu süreç belli bir disiplin içinde olurdu, hangi madene gönderilecekleri bölge kadılarına hükümle bildirilir ve gereken özeni göstermeleri istenirdi. ${ }^{49}$

Ancak bütün bu uyarılara rağmen yörüklerin istihdamında yine de bazı sorunlar yaşanmıştır. Örneğin maden organizasyonunda istihdam edilen yörükler, tıpkı Eflak taifesi gibi bazen görev yerlerine gitmeyip kaçmayı tercih etmişlerdir. Nitekim 28 Receb 983/2 Kasım 1575 tarihli Tanrıdağ yörüklerinin subaşısı olan Mustafa'ya gönderilen bir hükümde; Tanrıdağ yörüklerinden bir kısmının Kamengrad madenine gitmeyerek kaçtıkları ve ayrıca bunu alışkanlık haline getirdikleri ifade edilerek, herhangi bir mazereti bulunmadan madene gitmeyenlerin yakalanıp hapsedilmeleri ve ardından da merkeze gönderilerek kürek cezasına konulmaları sıkı bir şekilde tenbih edilmiştir. Belgeden anlaşılacağı üzere devlet, savunma ihtiyaçlarının karşılanabilmesi için madenlerin aksamadan çalışmasını öngörmüş ve madenleri sıkı bir denetim altına almıştır. ${ }^{50}$

Ancak Kamengrad madeninde çok fazla cevherin olması, yörüklerin tekrar madende görevlendirilmesini zorunlu kılmış ve Bosna beyi Ferhad'ın talebi üzerine merkezden "Naldöken ve Tanrıdağı yörüklerinin birer nöbetlisi rûz-ı hızırdan mukaddem varub hıdmetde olmaları için subaşılarına mü'ekked ahkâm-ı şerîf" gönderilerek yörükler tekrar madende görevlendirilmiştir. Bu hükümde yörüklerin madene

gruplar Osmanlı teşkilatını içinde bulundukları bilinmektedir. Osmanlılardan önceki dönemlerde de var oldukları bilinen martoloslar, Osmanlı devletinin ilk kuruluş yıllarından itibaren devlet teşkilatı içinde yer almışlardır. Illerleyen dönemlerde Balkanlardaki kalelerde martolosların hudut bekçisi rölünde olduklerı görülmektedir. Kanuni döneminde ise, martoloslar yalnızca hudutlarda değil, hudutların gerisinde de muhafız ve derbetçi olarak bulunmuşlardır. Bu bağlamda martoloslar, hudut boylarında kale muhafızlığı ve derbend ve geçitlerde bekçilik görevlerini yerine getirmişlerdir." Ayrıntı için bkz. Cengiz Orhonlu, Osmanlı Imparatorluğu'nda Derbend Teşkilatı, Eren Yayıncılık, ìstanbul 1990, s. 85-99.

${ }^{49}$ Altunbay, a.g.m, s. 794.

${ }^{50}$ BOA. A.DVNSMHM.d, 27/151, 28 Receb 983/2 Kasım 1575; Suraiya Faroqhi, Osmanlı Imparatorluğu ve Etrafındaki Dünya, Çev. Ayşe Berktay, Kitap Yayınevi, İstanbul 2010, s. 21.

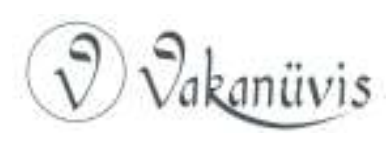


geldiklerinde uygun görevlere yerleştirilmeleri, etraftaki kalelerin toplarına göre fazlaca gülle ve mermi yapmaları ve yaptıkları miktarı da merkeze bildirmeleri tembihlenmiştir. ${ }^{51}$

Nihâyetinde yörüklerle ilgili sorunların ortadan kalktığı, Bosna beyinin merkeze gönderdiği bir dilekçeden anlaşılmaktadır. Şöyle ki, Bosna beyi, geçen yıl madene gelen Naldöken yörüklerinin çok dikkatli çalıştıklarını bu nedenle adı geçen yörükleri tekrar madende çalıştırmak istediğini merkeze gönderdiği dilekçede açık bir şekilde ifade etmiştir. Ayrıca yeterli miktarda top güllesi yapılamamasının nedeninin yörükler değil yağmur olduğunu belirterek, madende hala çok fazla demirin bulunduğunu bu nedenle yörüklerin madene gelmelerinin şart olduğunu önemle vurgulamıştır. ${ }^{52}$

Maden ocaklarındaki iş̧̧i sorununu bu şekilde çözen devlet, madenler için gerekli kömür, odun, zahire gibi diğer mühimmatı yine madene yakın köylerden tedarik etmiştir. Bu köy ve kazalardan bir veya bir kaçının bazı vergilerden muaf tutularak, madene odun, kömür, zahire ve diğer zaruri ihtiyaçları temin eden ${ }^{53}$ bu gruplara aynı zamanda "narhI cârî üzere" ödeme yapıldığı görülmektedir. ${ }^{54}$

Madene getirilen zahireyi muhafaza etmek onu temin etmek kadar önemliydi. Örneğin Kamengrad madeninin zahiresi ve diğer mühimmatı Banaluka'da saklanmaktaydı. Ancak Bosna beyine yazılan bir hükümde, Banaluka'nın zahire ve mühimmat saklamak için uygun bir yer olmadığı belirtilerek"zahîre Banaluka'da mı durmak efzâldir ma'den için, bir palanka mı tedarik evlâdır, ehl-i vukûf ile müşâvere edüb tahassun edesiz" ifadesinden de anlaşıldığı üzere, konu tartışıldıktan sonra, zahire

\footnotetext{
51 BOA. A.DVNSMHM.d, 33/669, 27 Zî́l-hicce 985/7 Mart 1578.

52 “.....top yuvalağı ma'deni zâhir olandan berü işleyüb ve Naldöken yörükleri za'îmi Muhammed yörükleri ile hıdmet-i mezbûrede küllî dikkat edüb lakin kesret-i bârân olmağla ancak yediyüz yuvalak dökülüb lakin vâfir cevher ihsâr olunub mezbûr za'îm Muhammed yine zikr olunan hıdmete ta'yîn olunmasını 'arz eyledüğün ecilden mezbur varub yine ol hıdmetde olmak içün emr-i şerîf gönderilmiştir......." BOA. A.DVNSMHM.d, 39/526, 4 Safer 988/21 Mart 1580.

53 Çağatay, a.g.m, s. 122.

${ }^{54}$ Altunbay, a.g.m, s. 795;BOA. A.DVNSMHM.d, 23/779, 18 Zî́l-ka'de 981/11 Mart 1574; Banaluka'da daha önce yuvalak saklandığı bilinmektedir. Ancak zamanla buradaki saklama koşullarının elverişsiz hale geldiği düşünülmektedir. Bkz. BOA. A.DVNSMHM.d, 23/243, 17 Receb 981/12 Kasım 1573.
}

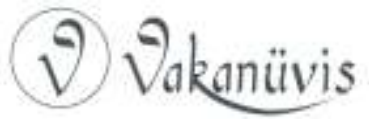


ve mühimmatın madene bir palanka yaptırılarak orada saklanmasına karar verilmiştir. ${ }^{55}$

Arşiv kayıtlarından da verimli bir demir madeni olduğu anlaşılan Kamengrad demir madeni hakkındaki belgelere 1580 tarihinden sonra rastlanılamaması, madende üretimin durduğunu göstermektedir. Nitekim madencilik sektörünün 1580 tarihinden itibaren büyük bir sarsıntı geçirdiği ve uzun süre kendisini toparlayamadığından bahsedilmektedir. Maden ocaklarının bir kısmının da yetkililerin ilgisizliğinden dolayı yıkım yaşadığı bu nedenle madenlerde deneyimli idarecilerin yani ehl-i vukûftan olanların görevlendirilmesi gerektiği de belirtilmektedir. ${ }^{56}$

17. yüzyılın başlarında Bosna'da bulunan demir ve bakır madeni kuyularının tamir edilerek tekrar açılması hususunda bölge idarecilerine emirler gönderildiği arşiv belgelerinden takip edilebilmektedir. Ancak Kamengrad'da bulunan demir madeni ilgili bilgilere rastlanamaması maden ocağının artık aktif bir şekilde işlemediğini düşündürmektedir. ${ }^{57}$ 18. yüzyılın ilk çeyreğine ait bir hükümde geçen, Banaluka'da bulunan demir madeninin harap bir durumda olduğu ve burada bulunan top döküm ustalarının tabya muhafızlığında görevlendirilmeleri hususundaki bir ifadeden de Kamengrad maden ocağının artık işlemediği ve atıl durumda olduğu anlaşılmaktadır. ${ }^{58}$

Devlet için stratejik bir öneme sahip olan bölgedeki maden işletmelerinin atıl kalmasının ardında Osmanlı devleti ve Avusturya arasındaki siyasi ve askeri hareketliliğin payı büyüktür. Bu nedenle devletin buralarla ilgilenememesi ve aynı zamanda madenlere deneyimli yöneticiler atayamaması maden ocaklarındaki işleyişin aksamasına neden olmuştur.

55 “.....ma'den-i mezbûr içinde münâsib görülen mahalde alçı tarîkiyle kifâyet mikdârı bir palanka binâ etdirüb ma'den-i mezbûrun mühimmâtın ve zahâ'irin içinde hıfz etdirüb...." BOA. A.DVNSMHM.d, 23/779, 18 Zî́l-ka'de 981/11 Mart 1574.

${ }^{56}$ Altunbay, a.g.t, s. 23.

57 BOA. A.DVNSMHM.d, 75/178, 16 Şevvâl 1013/7 Mart 1605; BOA. A.DVNSMHM.d, 78/1784, 16 Receb 1018/15 Ekim 1609; BOA.I.MDN, 3/178, 15 Receb 1126/27 Temmuz 1714.

${ }^{58}$ BOA. A.DVNSMHM.d, 129/746, 20 Rebî'ü'l-evvel 1132/31 Ocak 1720.

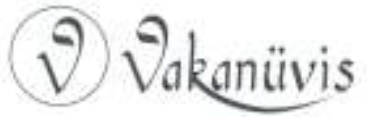


Genelde bir maden işletmesinin durum tesbitini yaptığımız bu çalışmada bilhassa maden işçilerinin istihdamında sorunlar yaşanması ve işçilerin sürekli madenden firar etmeleri, bizi Osmanlı'da maden iş̧̧isi olgusunun sorgulanmasına yöneltmiştir. Bu bağlamda yapacağımı diğer çalışmalarda bir maden işçisinin dünya algısını anlayabilmek için madende çalışmanın bir avantaj mı yoksa bir dezavantaj mı olduğu sorularına cevap aranmaya çalışılacaktır.

\section{Sonuç}

Osmanlı devletinin ilk dönemlerinde Anadolu ve Rumeli'ye yapılan fetihlerde birçok maden sahasının ele geçirildiği ve hemen organize edilerek tekrar kullanıma açıldığı ve aynı zamanda mîrî arazi içine dahil edilen bu madenlerle ilgili uygulamaların kanunnamelerle düzenlenerek sistemleştirildiği görülmektedir.

Büyük bir çoğunluğu mîriye ait olan madenlerin işletme usullerinin belirlenmesi ve konuyla ilgili gerekli hukukî düzenlemeler devletin yetki alanına girmiştir. Devlet madenleri, çoğunlukla devlet desteği ve nezareti altında işleterek, maden işletmelerini ve aynı zamanda maden reâyâsını koruma altına almıştır. Zirâ erken klasik dönemde hem Avrupa devletleri hem de Osmanlı devleti savaş için örgütlenmişlerdi ve Osmanlı devleti bu dönemde madencilik alanında Avrupa devletleri ile rekabet edebilecek bir seviyede idi. Bu nedenle madenler, genelde Osmanlı maliyesinin en önemli gelir kaynakları arasında yer alırken özelde ise ordunun mühimmatını karşılamaları açısından son derece önemli bir yere sahipti.

Sonuç olarak Osmanlılardan önceki dönemlerde de işletilen Kamengrad demir madeni, 16. yüzyılın ikinci yarısından sonra tekrar işletmeye açılarak, ordunun ve etraftaki kalelerin top güllesi ve mermisini kısa bir süre de olsa temin etmeye çalışmıştır. Ancak 16. yüzyılın sonlarına doğru maden hakkındaki bilgilerin kesilmesi bu dönemde madenciliğin geçirmiş olduğu sarsıntıya bağlanılabilir. Aynı zamanda 16. yüzyılın sonlarında başlayıp 17. yüzyılın başlarına kadar devam eden Avusturya-Osmanlı savaşının da bölgedeki madencilik sektörünü olumsuz yönde etkilediği hatta bu durumun 18. yüzyıla

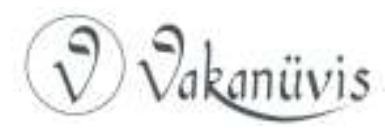


girerken sona eren II. Viyana kuşatması esnâsında da devam ettiği düşünülmektedir.

\section{Kaynakça}

\section{Arşiv Kaynakları}

T. C. Cumhurbaşkanlığı Devlet Arşivleri Başkanlığı Osmanlı Arşivi Divan-ı Hümayun Mühimme Defterleri

A.DVNSMHM.d. 10/300

A.DVNSMHM.d. $10 / 301$

A.DVNSMHM.d. $10 / 302$

A.DVNSMHM.d.16/47

A.DVNSMHM.d. $16 / 127$

A.DVNSMHM.d. 19/80

A.DVNSMHM.d. 19/82

A.DVNSMHM.d. 19/636

A.DVNSMHM.d. 23/243

A.DVNSMHM.d. 23/306

A.DVNSMHM.d. 23/333

A.DVNSMHM.d. 23/779

A.DVNSMHM.d. 26/744

A.DVNSMHM.d. 27/151

A.DVNSMHM.d. 33/669

A.DVNSMHM.d. 39/526

A.DVNSMHM.d. $75 / 178$

A.DVNSMHM.d. 78/1784

A.DVNSMHM.d. 129/746

Maden Mukâta'ası Kalemi Defterleri

D.MMK.d. 22697

İbnü'I-Emin Tasnifi, Me'âdin

IE.MDN. 3/178; $1 / 1$

\section{Araştırma Eserleri}

Agoston, Gabor, Barut, Top ve Tüfek: Osmanlı Imparatorluğu'nun Askeri Gücü ve Silah Sanayisi, Çev. Tanju Akad, İstanbul 2006.

Akdağ, Mustafa, Türkiye'nin iktisâdî ve İçtimâî Tarihi, Tekin Yayınevi, Ankara 1979. 
Akgündüz, Ahmet, Osmanlı Kanunnameleri ve Hukuki Tahlilleri, I. Kitap Osmanlı Hukukuna Giriş ve Fatih Kanunnameleri, Fey Vakfı, İstanbul 1990.

Akgündüz, Ahmet, Osmanlı Kanunnameleri ve Hukuki Tahlilleri, II. Kitap II. Bayezid Devri Kanunnameleri, Fey Vakfı, İstanbul 1990.

Altunbay, Mustafa, "Klasik Dönemde Osmanlı'da Madencilik", Türkler, C.X, Ankara 2003, s. 791-801.

Altunbay, Mustafa, Osmanlı Döneminde Bir Maden İşletmesinin Tarihi Süreci: Sidrekapsi, İstanbul Üniversitesi Sosyal Bilimler Enstitüsü, Yayımlanmamış Doktora Tezi, İstanbul 2010.

Anhegger, Robert, Beitraege zur Geschichte des Bergbaus im Osmanischn Reich I. Europaeische Türkei, İstanbul 1943.

Aydüz, Salim, "Tophane-i Amire ve Osmanlılarda Top Dökümü", Osmanlı Askeri Tarihi, İstanbul Aralık 2011, s. 21-54.

Bilgin, Arif-Ümit Ekin, "Bir Kimliğin Dönüşümü: "Asker”likten “AskerEsnaf"lığa", Akademik incelemeler Dergisi, 2007, 2.1, s. 215-229.

Bostan, İdris, "16.yy. Başlarında Tophane-i Amire ve Top Döküm Faaliyetleri", Halil Inalcık Armağanı I, Ankara 2009, I, s. 249-280.

Bölükbaşı, Ömerül Faruk, 18. Yüzyılın Ikinci Yarısında Darphâne-i Amire, İstanbul Bilgi Üniversitesi Yayınları, İstanbul 2013.

Çağatay, Neşet, "Osmanlı İmparatorluğu'nda Maden İşletme Hukuku”, Ankara Üniversitesi Dil Ve Tarih Coğrafya Fakültesi Dergisi, C.II, S.I, Ankara 1943, s. 117-126.

Çağatay, Neşet, İslam Dünyasında ve Batıda iş Ortaklıkları Tarihi, Çeviren: Şehnaz Layıkel, Tarih Vakfı Yurt Yayınları, İstanbul 1999.

Diamond, Jared, Tüfek, Mikrop ve Çelik, Tübitak Popüler Bilim Kitapları, Ankara 2010.

Darling, Linda T., Revenue-Raising\&Legitimacy Tax Collection\&Finance Administration in the Ottoman Empire 1500-1660, E.J. Brill, Leiden-Newyork. Köln 1996.

Dursun Bey, Tarih-i Ebu'l-feth, Tarih-i Osmanî Encümeni Mecmuası, C. V-VI, S. 26-38, istanbul, 1330.

Emecen, Feridun, "Banaluka" Türkiye Diyanet Vakfı İslâm Ansiklopedisi (DIA), C.V (1992), s. 49-51.

Ergenç, Özer, 16. Yüzyılın Sonlarında Bursa, Türk Tarih Kurumu, Ankara 2006.

Faroghi, Suraiya, Osmanlı Imparatorluğu ve Etrafındaki Dünya, Çev. Ayşe Berktay, Kitap Yayınevi, İstanbul 2010.

Hafizovic, Fazileta,"Posjedi zvaničnika I njihovih porodica u Kliškom Sandžaku u XVI stoljeću. "Znakovi vremena-Časopis za filozofiju, religiju, znanost i društvenu praksu 48-49 (2010), s. 228-257. 
Handzic, Adem, "Rudnici U Bosni Od Druge Polovine XV do Početka XVII St.", Prilozi, LXXIX, Sarajevo 1987, s. 355-356.

Handzic, Adem, Osmanlı Imparatorluğunda Devlet ve Ekonomi, Ötüken Kitap, İstanbul 2003.

İnalcık, Halil, Osmanlı Imparatorluğunun Sosyal ve Ekonomik Tarihi 13001600, Çev. Halil Berktay, Eren Yayıncılık, C.I, İstanbul 2004.

İnalcık, Halil, Hicrî 835 Tarihli Sûret-i Defter-i Sancak-i Arvanid, Türk Tarih Kurumu, Ankara 1987.

İnalcık, Halil, Osmanlı Imparatorluğu Klasik Çağ (1300-1600), Çev. Ruşen Sezer, Yapı Kredi Yayınları, İstanbul 2008.

İnalcık, Halil-Robert Anhegger, Kânûnnâme-i Sultânî Ber Mûceb-i Örfî Osmânî, II. Mehmed ve II. Bayezid Devirlerine Ait Yasakname ve Kanunnameler, Türk Tarih Kurumu Yayınları, Ankara 1956.

İnbaşı, Mehmet, "Üsküp”, Türkiye Diyanet Vakfı İslâm Ansiklopedisi (DiA), C.42 (2012), s. 377-380.

Katic, S., I. Ilić and D. Živković, "Copper Productıon In Majdanpek In Sıxtıes And Seventies Of The 16th Century", Jour nal of Mining and Metallurgy, 45 (2), 2009, s.213-220.

Kul, Eyüp, "1703 Tarihli Bir Rapora Göre Kratova, Köstendil, Üsküp, Trepçe ve Jejene Madenlerinin Islahı", Belleten, C. LXXX, S.288, Ankara 2016, s.395-410.

Orhonlu, Cengiz, Osmanlı Imparatorluğu'nda Derbend Teşkilatı, Eren Yayıncilık, İstanbul 1990.

Oruç, Hatice, "15. Yüzyılda Bosna Sancağı ve Idarî Dağılımı", Ankara Üniversitesi Osmanlı Tarihi Araştırma ve Uygulama Merkezi Dergisi (OTAM), 18/2005, Ankara 2006, s. 249-271.

Oruç, Hatice, "Administrative Division of the Bosnian Sandjak in the 16 th Century", Ankara Üniversitesi Osmanlı Tarihi Araştırma ve Uygulama Merkezi Dergisi (OTAM), 25/Bahar 2009, Ankara, 99-148.

Özvar, Erol, Osmanlı Mâliyesinde Mâlikâne Uygulaması, Kitabevi, İstanbul 2003.

Parry, Vernon J, "Barut", The Encyclopaedia of Islam (EI2), I, Leiden 1986, s. 1062-1066.

Refik, Ahmed, Osmanlı Devrinde Türkiye Madenleri, Enderun Kitabevi, istanbul 1989.

Sahillioğlu, Halil, "Bir Mültezimin Zimem Defterine Göre XV. Yüzyıl Sonunda Osmanlı Darphane Mukâta'aları", istanbul Üniversitesi iktisat Fakültesi Mecmuası, C.23, S.1-4 (1963), s. 145-208.

Şemsettin Sami, Kâmûsu'l-Alâm, İstanbul 1308.

Tabakoğlu, Ahmet, Gerileme Dönemine Girerken Osmanlı Maliyesi, Dergah Yayınları, ìstanbul 1985.

Tabakoğlu, Ahmet, Türk iktisat Tarihi, Dergah Yayınları, İstanbul 1998. 
Taş, Hülya, XVII. Yüzyılda Ankara, Türk Tarih Kurumu, Ankara 2006.

Tızlak, Fahrettin, "Osmanlı Devleti'nde Madencilik", Osmanlı, C.3, Yeni Türkiye Yayınları, İstanbul 1999, s. 313-317.

Trubelja, Fabijan-Ljudevit Baric, Minerals of Bosnia and Herzegovina, Sarajeva 2011.

Uzunçarşılı, İsmail Hakkı, Osmanlı Tarihi, C.1, Türk Tarih Kurumu Basımevi, Ankara 1988.

Uzunçarşılı, İsmail Hakkı, Osmanlı Tarihi, C. II, Türk Tarih Kurumu Basımevi, Ankara 1988.

Yüksel, Hasan, Osmanlı Döneminde Keban-Ergani Madenleri: 1776-1794 Tarihli Maden Emini Defteri, Sivas 1997. 